\title{
CRIANÇAS COM ENCEFALOPATIA NAO EVOLUTIVA: AVALIAÇAO AUDIOLOGICA E PROTESE AUDITIVA
}

\section{Pôster}

Autores deste trabalho:

Cilmara Cristina Alves da Costa Levy: FCMSCSP

Sergio Rosemberg: FCMSCSP

Área do Trabalho: Fonoaudiologista

Número de inscrição: 5445

Data da submissão:30/08/2016 às 16:16

\section{Justificativa}

Estudos envolvendo a investigação de problemas auditivos em recém-nascidos de risco tem gerado inquietudes nas áreas médicas e terapêuticas, pois os resultados apontam incidência significativas de casos de perda auditiva. Os fatores que concorrem para as alterações auditivas e neurológicas são muitas vezes os mesmos, podendo ocorrer nos períodos pré, peri e pós-natal. No entanto, o comprometimento auditivo e neurológico depende do momento e da intensidade do acometimento, que inclui os diversos fatores das variantes clínica em cada caso. Quando se detecta uma perda auditiva, a seleção e o benefício da prótese auditiva tem se mostrado eficazes

\section{Objetivo(s)}

Avaliar a capacidade auditiva de crianças com encefalopatia crônica não evolutiva (ECNE) independentemente da suspeita da perda auditiva. Determinar a relação entre perda auditiva e etiologia e avaliar nos pacientes com perda auditiva o benefício da prótese auditiva.

\section{Método(s)}

Avaliação neurológica, otorrinolaringológica e fonoaudiológica. Na avaliação audiológica incluiu imitanciometria, pesquisa do reflexo do muculo do estribo, emissões otoacústicas, avaliação audiológica e em caso de perda auditiva avaliação em campo livre com e sem prótese auditiva. 


\section{Resultado(s)}

Das 46 crianças avaliadas, encontraram-se 24 (52\%) com algum grau de perda auditiva sensorioneural e $22(48 \%)$ sem perda auditiva. Constatou-se relação estatisticamente significante entre perda auditiva e etiologia. Quanto a etiologia encontrada nas 46 crianças, a maior porcentagem é de encefalopatia hipóxia isquemica seguida de processos infecciosos e Kernicterus. Quanto a suspeita de perda auditiva, nas 16 (35\%) cujos pais tiveram suspeita, o percentual de algum grau de perda auditiva foi de $56 \%$ e nas $30(65 \%)$ cujos pais não a tiveram a avaliação a audiológica revelou que $50 \%$ dos casos apresentou perda auditiva.

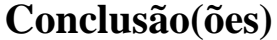

Das crianças avaliadas mais da metade apresentou perda auditiva, no entanto, não houve relação estatisticamente significante entre etiologia e suspeita de perda auditiva. Assim considerando que não é possível prever qualquer perda auditiva a partir da suspeita e recomendado a avaliação auditiva em todas as crianças com ECNE. O benefício da prótese auditiva foi estatisticamente significante em todos os casos de perda auditiva sensorioneural. 